\title{
The Guide of Japanese Energy Management Standard To China
}

\author{
Xing Zhao ${ }^{1, a^{*}}$, Zetao Wang ${ }^{2, b}$ and Xuedong Jing ${ }^{2, c}$ \\ ${ }^{1}$ Chongming Institute of Quality and Technical Supervision, China \\ ${ }^{2}$ Shanghai Institute of Technology, China \\ azx13916323142@163.com, 'b1164285386@qq.com, jingkd2003@aliyun.com
}

\begin{abstract}
Keywords: energy management stands; energy saving; legal effect; boilers operation
Abstract. The energy managment standards specify in-factory rules of operation control, measurement and recording keeping, and maintenance and inspection points and frequencies of energy using equipment for purpose of improving energy saving. However, it is the researches on energy standard that have been neglected in China. As a result, the boiler operator in factory actually don't know how to take action toward energy conservation and how to improve the operation of boilers. All of these should attribute to their having no specified rules ,applied to energy saving ,to guide their operation. Japanese energy management system of the boiler have been the leader of the world. Not only have they established a series of complete energy management stand ards[1],but also they have made it possess legal effect and force enterprises to observe. Based on these,this thesis will analyze Japanese energy management standards and propose some ideas for energy saving in China.
\end{abstract}

\section{Introduction}

The low energy efficiency is a big obstacle for sustainable development of Chinese economy. Compared with the advanced level of the world, there is much gap in energy efficiency and energy consumption per unit of out-put value in China. In reality energy consumption per unit of output value in China is twice as that of the average level of the world. As for energy efficiency, the value of it in China is about $33 \%$, which is $10 \%$ lower than that in the advanced counties[2]. One reason is that the energy management standard of China is unpractical and inr complete compared with that of Japan, which is acknowledged around the world to be the model for its energy saving achievements.

As far as boilers is concerned, the total of boilers is 6412,00 , most of which are solid fuel-fired boilers; and how to improve the energy efficiency of boilers become urgent. Although the energy saving of boilers involves the advancement of energy-save technology and the improvement of energy management, this paper mainly studies Japanese energy management standard and proposes some suggestions for the energy saving of boilers in China. Based on the previous experiences of boiler energy saving in the developed countries such as Japan, the best way to improve boiler thermal efficiency is not to develop new energy-save technology, but to establish a complete energy management system, which always tends to be most economical and practical.

\section{Problems in Energy Saving Standards of China}

At present in China,the technology specifications of energy saving of the boiler mainly include Supervision Regulation on Saving Energy Technology for Boiler[3] and Energy Efficiency Test and Evaluation Regulation for Industrial Boiler[4]. However they only involve the operations and the specifications of the boiler in test or in design phase, and don't give operators the detailed and complete operations guide of energy saving for running a boiler. As a result, operators feel confused and don't know how to achieve the energy saving of boilers under different load.

Besides the technology specifications above, there are still energy saving management standards including Monitoring and Testing for Energy Saving of Coal Fired Ind ustrial Boilers[5],Economical Operation of Industrial Boilers[6] and General Specification for Ind ustrial Boilers[7]. Monitoring and Testing for Energy Saving of Coal Fired Industrial Boilers is mainly used for evaluating the boiler thermal efficiency, the exhaust gas temperature, air ratio, the unburned carbon in the slag and the boiler surface temperature. It doesn't provide boiler operators the detailed specifications for energy saving. 
Ecnomical Operation of Industrial Boiler also has the problems above, and it can only be applied in the fixed steel boiler using coal,oil and gas as fueland water as the medium, and not applicable for the exhaust heat boiler, the electric boiler and the organic heat carrier boiler.

However, Japanese energy management standard almost covers all kinds of boilers and other energy-consuming devices. The most important is that Japan government has forced all enterprises to implement it. Whereas in China, all regulations above are just energy saving standards for recommendation.

\section{Analysis of the energy management standard in Japan}

Japanese energy management standards specify various rules of operation control, which always describes general control items of the overall energy-consuming equipment and their detailed descriptions. These control items involve all equipment of various kind of boilers, including combustion equipment, heating equipment, air-conditioning equipment and powergeneration-dedicated equipment, etc.whose descriptions are so detailed that the operator can clearly know what action should do towards the same vector--energy saving. When a boiler in a Japanese factory can't meet the minimum standards recommended, the boiler operators only need to observe the energy management standards and find out operation descriptions of that kind of the boiler(the operations vary with different kind of boilers).Although measures of energy saving in this standard have been described in detail and practically, some operations still need to observe more detailed standards, such as criteria of combustion air ratio for boiler combustion, targets of boiler waste gas temperature and criteria of combustion air ratio for furnace combustion, etc. Operating and adjusting the boiler based on detailed guidelines and descriptions you have found may improve energy efficiency of this boiler.

The following tables(table 1 and table2 ) are just parts of Japanese energy management standard[1], which mainly introduces and analyzes the energy management standards.By comparing the standards involved energy saving in China, it can be found the gap of energy management standards between two nations.

Table 1 Setup Items of the Management Standards and Their Details(Partial)

\begin{tabular}{|c|c|c|}
\hline Operation and control & Measurement and record & Maintenance and inspection \\
\hline $\begin{array}{l}\text { 1. Combustion equipment } \\
\text { (1) Fuel combustion control } \\
\text { (1)An air ratio shall be controlled } \\
\text { according to combustion equipment } \\
\text { and fuel type. } \\
\text { (2) For combustion equipment, the } \\
\text { air ratio shall be reduced on the } \\
\text { basis of Table } 1 \text { and } \\
\text { (3)For multiple pieces of equipment, } \\
\text { loads shall be adjusted to control the } \\
\text { overall thermal efficiency. } \\
\text { (4)The fuel properties shall be } \\
\text { controlled so that combustion } \\
\text { efficiency is improved. }\end{array}$ & $\begin{array}{l}\text { 2.Combustion equipment } \\
\text { (2)Measurements and } \\
\text { record keeping relating to } \\
\text { fuel combustion } \\
\text { Measurements and } \\
\text { recording of fuel supply } \\
\text { rates, exhaust-gas } \\
\text { temperature, and the } \\
\text { amount of oxygen } \\
\text { remaining in }\end{array}$ & $\begin{array}{l}\text { 3.Combustion equipment } \\
\text { (3)Maintenance and } \\
\text { inspection of combustion } \\
\text { equipment } \\
\text { Combustion equipment shall } \\
\text { be periodically inspected and } \\
\text { maintained to keep it in good } \\
\text { condition. }\end{array}$ \\
\hline
\end{tabular}


Table2 Setup Items of the Management Standards and Their Details(Partial)

\begin{tabular}{|c|c|c|}
\hline Operation and control & $\begin{array}{l}\text { Measurement and } \\
\text { record }\end{array}$ & $\begin{array}{l}\text { Maintenance and } \\
\text { inspection }\end{array}$ \\
\hline $\begin{array}{l}\text { 33. Waste heat recovery and use } \\
\text { (1) Standards for waste heat recovery and use } \\
\text { (1)Waste gas temperature or waste-heat recovery rate } \\
\text { shall be controlled according to exhaust-gas } \\
\text { discharge equipment. } \\
\text { (2)Waste gas temperature and waste-heat reco very } \\
\text { rate shall be controlled on the basis of Table } 2 \text { and } 4 . \\
\text { (3)For steam drain, the temperature, quantity, and } \\
\text { properties shall be controlled. } \\
\text { (4)For recovery and use of sensible heat, latent } \\
\text { heat,pressure, combustible components, etc. of } \\
\text { heating solid and fluid, reco very ranges shall be } \\
\text { controlled. } \\
\text { (5)For waste heat, an effort shall be made to use it } \\
\text { appropriately according to its temperature, } \\
\text { equipment operating conditions, etc }\end{array}$ & $\begin{array}{l}\text { 3. Waste heat } \\
\text { recovery and use } \\
\text { (2) Measurements } \\
\text { and record keeping } \\
\text { relating to waste heat } \\
\text { To grasp the waste } \\
\text { heat status to } \\
\text { promote its use, the } \\
\text { temperature, heat } \\
\text { quantity, } \\
\text { components, etc. } \\
\text { shall be periodically } \\
\text { measured and } \\
\text { recorded. }\end{array}$ & $\begin{array}{l}\text { 3. Waste heat } \\
\text { recovery and use } \\
\text { (3) Maintenance } \\
\text { and inspection of } \\
\text { waste heat reco very } \\
\text { equipment } \\
\text { For waste heat } \\
\text { recovery } \\
\text { equipment, } \\
\text { Removal of } \\
\text { contamination from } \\
\text { heat-transfer } \\
\text { surfaces etc. } \\
\text { Heating medium } \\
\text { leakage prevention, } \\
\text { etc. shall be } \\
\text { periodically } \\
\text { inspected and } \\
\text { maintained. }\end{array}$ \\
\hline
\end{tabular}

Table 1 and table 2 above describe the detailed measurement and operation of two control items,combustion equipment and waste heat recovery and use, in the energy management standard of Japan. Specified measurements for saving energy are divided into 3 parts,operation and control,measurement and record and maintenance and inspection. Every part of these measurements is also consists of several detailed operations. As described in table 1, operation and control of combustion equipment is divided into 4 parts, (1)(2)(3), which shows that air ratio, loads and fuel properties should be controlled if the energy efficiency of this boiler need to be improved. Moreover, it has also established the criteria of combustion air ratio for boiler combustion to let the operator understand how to control air ratio. This means that the energy management standard not only tells boiler operators the detailed operations for energy saving but also supplies the complete technology criteria to for them.

Table 3 Examples of Application to Equipment(Partial)

\begin{tabular}{|c|c|c|c|c|c|}
\hline \multirow{2}{*}{$\begin{array}{l}\text { Equipme } \\
\text { nt, unit or } \\
\text { device } \\
\text { name }\end{array}$} & \multirow{2}{*}{$\begin{array}{l}\text { Classification } \\
\text { of equipment } \\
\text { or items }\end{array}$} & \multicolumn{3}{|c|}{ Control items to be set } & \multirow{2}{*}{ Remarks } \\
\hline & & Operation & $\begin{array}{l}\text { Measureme } \\
\text { nt\& } \\
\text { recording }\end{array}$ & $\begin{array}{l}\text { Maintenanc } \\
\text { e inspection }\end{array}$ & \\
\hline \multirow{5}{*}{$\begin{array}{l}\text { Industrial } \\
\text { steam } \\
\text { boilers }\end{array}$} & $\begin{array}{l}\text { 1.Fuel } \\
\text { combustion } \\
\text { control }\end{array}$ & $\begin{array}{l}\text { (1) (2) (3) } \\
\text { (4) }\end{array}$ & & & See Table 1 \\
\hline & $\begin{array}{l}\text { 2-1.Heating } \\
\text { equipment, etc. }\end{array}$ & (1) (7) (10) & & & $\begin{array}{l}\text { (1) applies if steam, etc.is used } \\
\text { for fuel heating,etc. and (10) } \\
\text { applies to steam to be } \\
\text { produced. }\end{array}$ \\
\hline & $\begin{array}{l}\text { 3. Waste heat } \\
\text { recovery }\end{array}$ & (1) (2) (3) & & & See Table 2 \\
\hline & $\begin{array}{l}\text { 5-1.Heating } \\
\text { insulation and } \\
\text { heat reserving }\end{array}$ & & & (1) (2) & \\
\hline & $\begin{array}{l}\text { 6-1.Electric } \\
\text { power } \\
\text { application }\end{array}$ & (3) (6) & & (1) (2) & $\begin{array}{l}\text { Set to auxiliary equipment } \\
\text { such as pumps,fans, etc. }\end{array}$ \\
\hline
\end{tabular}


Table 3 is also a part of examples of application to equipment in Japanese energy management standards, and it only involves industry steam boiler. It lists the specific energy-consuming equipment of industry steam boiler and shows the required standard control items for the equipment in the standard control item numbers. The control item numbers are compliant with those in table1 or table 2(a part of numbers are mentioned in table 1 and table 2).

Table 3 lists various control items of industry steam boiler, and it also shows the required operations of these equipment.That is, when a industry steam boiler need to meet requirements of minimum criteria of energy consumption, the measurements of fuel combustion control should be carried out according to (1)(2)(3), described in table 1. As for waste heat recovery and use ,(1)(2)(3) should be taken out. (only the combustion and waste heat recovery and use here is shown). What cited and analyzed above is just a small part of Japanese energy management standard,which only describes briefly the rules of the combustion equipment and waste recovery. In fact,this standard not only involves rules of ind ustrial steam boilers, but also it even includes almost all kinds of boilers or other energy - consuming devices in Japan,such as air conditioners and steam boilers for hot-water supply, mental heating furnaces and heat treatment furnaces and blast furnace, etc. This indicates that Japan has established a complete, detailed and practical energy management system. All of these attribute to Japanese sufficient research on energy management. However in China, the width and depth of the research on energy management is far behind that of Japan. Based on the domestic documents of boiler energy saving, it is clearly shown that the technical specifications related to energy saving of the boiler in China are quite incomplete and unpractical.

\section{Guides of Energy Saving to China}

The most important reason for Japanese realizing the targets of energy saving and emission reducing is that it has established the energy management standard. All enterprises in Japan are required to execute it, which has been regarded as an effective method to manage energy.Based on the analysis of Japanese energy management standard, the following advantages can be found.

(1)Japanese energy management standard is comprehensive. Its standard includes combustion equipment, heating equipment, air-conditioning equipment, waste heat recovery and use, powergeneration-dedicated, cogeneration equipment, prevention of heat loss caused by radiation, prevention of electrical loss caused by resistors, electric power application equipment, lighting equipment, etc. Almost all energy consuming equipment and energy saving measurement are involved.

(2)Japanese energy management standard has provided a standardized technology specification. Any energy cons uming equipment has been specified with strict standards. Some involved example are as described in table 1 and table 2.

(3) Japanese energy management standard quantifies indicators. The standard specifies parameters setting of some device, which helps the boiler operators take clear and right action towards energy saving.

Based on the awareness of the disadvantages of energy management specification in China, and analysis of Japanese energy management standard, the following suggestions may be practical and useful for energy saving and emission reducing.

(1)The idea that energy saving only depends on updating energy-consuming devices completely isn't realistic . In reality, the tools of energy analysis and energy management are proved to be more effective. China can also realize the targets of energy saving through combination of updating devices and establishing energy management standard.

(2)According to the equipment category, operation standards, operating rules and energy-consuming standards of corresponding equipment should be established. As a result, enterprises can make energy saving plans and achieve its energy saving goal step by step.

(3)All parameters about energy saving and emission reducing should be quantified as much as possible. Enterprises should understand their targets of energy saving and emission reduction clearly 
and then make the specific and practical plans on the basis of these quantified parameters. Besides, through the qualified parameters, the governments can also evaluate situation of energy saving and emission of all enterprises.

(4)The corresponding laws should be legislated to specify enterprise's responsibility of energy saving, and the corresponding punishments should also be listed in detail for breaking the energy saving law.

\section{Conclusions}

(1) In China, the situation of energy waste is very serious, and the energy saving specifications is also incomplete and unpractical.

(2)There is a great gap between China and Japan in energy saving. The main cause isn't that energy saving technology falls behind that in Japan, but that the concept and system of energy management are still not established.

(3) China could learn the essence of Japanese energy management standard, and make its rules and laws related to energy management in long term.

\section{Acknowledgments}

The authors own gratitude to Shanghai Municipal Bureau of Quality and Technical Supervision for it's financial supporting (Fund number:2013-27).

\section{References}

[1] Mizuho Tanaka,Energy Management Standards,Eco-Check-Network-Japan.

[2]Shangwu Wang,Potential Analysis of China IB Industry's Energy-saving and Some Suggestions, In Chinese, Ind ustrial Boiler,2005

[3] General Administration of Quality Supervision,Inspection and Quarantine of the people's Republic of China,S upervision Regulation on Saving Energy Technology for Boiler,2010

[4] General Administration of Quality Supervision,Inspection and Quarantine of the people's Republic of China ,Energy Efficiency Test and Evluation Regulation for Ind ustrisal Boiler,2010

[5] General Administration of Quality Supervision,Inspection and Quarantine of the people's Republic of China, monitoring and testing for energy saving of coal fired ind ustrial boilers,2009

[6] General Administration of Quality Supervision,Inspection and Quarantine of the people's Republic of China, Ec nomical operation of industrial boilers,2007

[7] State Economic and Trade Commission of the People's Republic of China, General specification for ind ustrial boilers, 2002 